4.Вопрос возможного обучения в СГУ иностранных студентов из стран дальнего зарубежья интересует и волнует многих студентов. Обучающиеся иностранцы «по-соседству»в Медицинском университете заметны. Высказывались следующие пожелания: «чтобы их не было слишком много», «после обучения необходим их отъезд на родину».

Такое настроение молодежи складывается в результате обеспокоенности высказываниями на самом высоком уровне и публикациями в СМИ, научных журналах на темы о «демографическом кризисе» в стране, который в основном касается воспроизводства славянских народов, об уменьшении доли русских в населении Российской Федерации, о том, что это приобрело характер устойчивой тенденции [4]. Большинство студентов понимают, что будет происходить дальнейший рост миграции в Россию, особенно из Закавказья, Средней Азии, Китая и других государств «ближнего» и «дальнего» зарубежья, этнически чуждых славянскому этносу народов.

Стремление к добрым отношениям с людьми разных национальностей, что прослеживается в высказываниях большинства студентов, сочетается с желанием сохранить собственную культурную идентичность. Жесткая позиция в отношении национальных проблем отнюдь не является следствием отрицания межнациональной толерантности. Она, по-видимому, и здесь можно согласиться со многими авторами, стоящими на схожих позициях, служит способом самозащиты в условиях сокращения и размывания восточнославянского ядра Российского государства [5]. Процесс должен быть двусторонним, что предполагает также и повышение толерантности мигрантов к принимающему обществу.

\section{Библиографический список}

1. Материалы Саратовского областного комитета по статистике: Статистический сб. Саратов, 2005. 171 с.

2. Витковская Г.С. Миграция и мигрантофобия в Приволжском регионе: Саратовская область // Миграционная ситуация в регионах России. Вып. 2. Приволжский федеральный округ / Под ред. Ж. Зайончковской. М., 2004. 201 с.

3. Ковалев Е.М., Штейнберг И.Е. Качественные методы в полевых социологических исследованиях. М., 1999. 384 с.

4. Руткевич М.Н. Воспроизводство населения и социально-демографическая ситуация в России // Социс. 2005. №7. C. 22-30.

5. Гаврилов Ю.А., Кофанова Е.Н., Мчедлов М.П., Шевченко А.Г. Сфера политики и межнациональные отношения в восприятии религиозных общностей // Там же. № 6. C. 56-70.

УДК 504 (470.44)

\title{
ИЗУЧЕНИЕ ПРИРОДНЫХ И ТЕХНОГЕННЫХ ГЕОЭКОЛОГИЧЕСКИХ РИСКОВ НА ТЕРРИТОРИИ ГОРОДА САРАТОВА
}

\section{В.К.Штырова, О.Е.Нестерова}

Саратовский государственный университет, кафедра геоморфологии и геоэкологии E-mail: Nesterova@sgu.ru

В статье рассматривается понятие геоэкологического риска, его виды. Приводится характеристика природно-техногенных процессов и проявлений факторов природного и техногенного рисков. Обосновывается возможность районирования территории города по степени проявления риска.

\section{Studying of Natural and Technogenic Geoecological Risks of the City Saratov}

\section{V.K.Shtyrova, O.E.Nesterova}

The concept of geoecological risk, its kinds is considered in article. The characteristic of natural-technogenic processes and display of factors of natural and technogenic risks is resulted. The opportunity of division into districts of territory of city on degree of display of risk is proved in article.

Как и в большинстве крупных городов, в Саратове быстро ухудшается качество окружающей

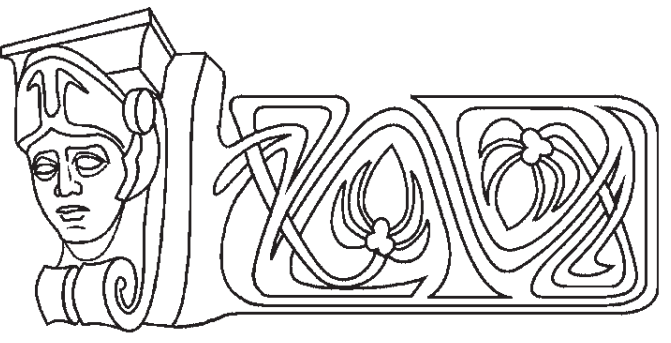

среды, повышается экологический и геоэкологический риск проживания людей вследствие неудержимого процесса урбанизации и активизации техногенного воздействия на природу. В результате происходит увеличение заболеваемости, смертности населения, ухудшение качества жизни.

Любой опасный природный процесс - это результат нарушения равновесного состояния, вызванного изменениями внешних воздействий со стороны атмосферы, литосферы, гидросферы или техносферы.

Геоэкологический риск определяется вероятностью развития нежелательных природных или природно-техногенных явлений в окружающей среде в результате активизации процессов, создающих угрозу людям, ухудшающих экологическую обстановку в городе и способствующих преждевременному износу и выходу из строя зданий и сооружений. Развитие факторов геоэкологичес- 
кого риска и их проявление зависит от состава и состояния среды, а также вида и интенсивности антропогенного воздействия [1].

По масштабу А.Л.Рагозин [2] риск подразделяет на локальный, региональный, субрегиональный и глобальный.

По происхождению выделяют природный (сейсмический, оползневой, лавинный, абразионный, наводнения и др.) и техноприродный риск (переработка берегов водохранилищ, подтопление территории, техногенные оползни и др.).

Решение проблемы оптимизации городских территорий, пораженных техногенным воздействием, предполагает применение различных методов и видов деятельности - технологических, экономических, санитарно-гигиенических, архитектурно-планировочных [3].

В рамках исследования на первоначальном этапе нами проведена интегральная оценка всех факторов природного, техноприродного и техногенного риска на территории Саратова. Такая оценка характеризует степень геодинамической и социально-экологической опасности территорий, а в условиях рыночных отношений она важна для определения дифференциации стоимости городской земли.

Для формирования правильной экологической политики в городах необходимо, на наш взгляд, выявление территориальной дифференциации степени геоэкологического риска. Для этого можно воспользоваться методами эколого-геоморфологической оценки рельефа и морфоструктурного районирования [4].

Под природно-техногенными опасностями обычно понимаются процессы и явления, развивающиеся в геологической среде в результате техногенных воздействий. На территории города, где такие воздействия особенно сильные, появляются новые или усиливаются медленно протекающие природные процессы. Они могут приводить к преждевременной деформации зданий и ускоренному разрушению подземных коммуникаций, что усугубляет экологическую обстановку, увеличивает социально-экологическую напряженность и создает дискомфорт жителям города, а в ряде случаев представляет угрозу для их жизни. Приводим характерные для территории Саратова природно-техногенные процессы, являющиеся потенциальными факторами риска.

Саратов расположен в зоне повышенной тектонической активности, обусловленной пересечением здесь континентальных разломов. В связи с этим коллективом авторов под руководством Г.И.Худякова описана и обоснована концепция геоморфоблокового строения территории города [5]. Действительно город расположен на стыке двух разновысотных денудационных равнин олигоцен-миоценового и раннеплейстоценового возраста, разделенных высоким сильно эродированным уступом. Главным признаком геоморфоблоков, по мнению авторов, является сочетание контрастных по высоте элементов рельефа, разделенных глубинными разломами [6].

Расположение Саратова в зоне неоднородных в геолого-геоморфологическом отношении геоморфоблоков обусловило вертикальное (до 100 м) и густое горизонтальное расчленение рельефа, сложную инженерно-геологическую, гидрологическую и как следствие геоэкологическую обстановку, ухудшающуюся с ростом города. Границы блоков совпадают с крупными эрозионными долинами, активными оврагами, заложенными по разрывным нарушениям или резким перегибам склонов (контакт Лысогорского плато с Приволжской моноклиналью). Зоны контакта блоков тектонически активны, поэтому представляют собой геоэкологически опасные участки и являются зоной геоэкологического риска («наведенная» сейсмичность, активные и стабильные оползни, линейная и плоскостная эрозия, суффозия, подтопление, заболачивание, геопатогенные зоны). Многие малые реки и овраги Саратова заложены по тектоническим нарушениям. Примером является Глебучев овраг, где наблюдается сложная геоэкологическая обстановка вследствие подтопления, обусловленного не только геолого-геоморфологическим строением, но и интенсивным антропогенным воздействием.

Учет структурно-геоморфологических особенностей и локализации морфоструктурных узлов, связанность с ними природно-техногенных явлений необходимы для адаптации городского населения и хозяйства к почти неизбежному соседству, тем более, что в северо-восточной части города расположено много эксплуатационных скважин и подземные газохранилища.

Подтопление грунтовыми водами территории Саратова - давняя и постоянно обостряющаяся проблема. Основная причина регионального подтопления в городе - это увеличение питания грунтовых вод из-за утечек водонесущих коммуникаций, фильтрации из прудов, строительных котлованов, поливов зеленых насаждений, перераспределения снега при очистке улиц, таяния над теплонесущими коммуникациями и подземными сооружениями. Сильно сказывается на уровне грунтовых вод ухудшение естественной дренированности вследствие ее перепланировки при строительстве (выравнивание рельефа путем засыпки овражно-балочной сети, долин мелких речек и ручьев, например руч. Белоглинка) и отсутствие инженерного дренажа.

В настоящее время подтопленной считается около 10\% городской территории. Затопление подвалов, зданий и подземных коммуникаций, снижение несущей способности грунтов и как следствие этого преждевременные деформации и выход из строя сооружений, увеличение в городе комаров, рецидивов заболеваний, угнетение растительности - таков результат подтопления. Этот процесс усиливает проявление оползней, эрозии, 
суффозии, загрязнения грунтовых вод, активизирует коррозию трубопроводов.

Катастрофические процессы рельефообразования - оползневые. В пределах городской территории оползневыми процессами поражено 23,5 км², общая протяженность оползневых склонов 16 км. Развитию оползневых процессов способствуют геологические, гидрогеологические условия территории, тектоническая нарушенность и наличие зон повышенной трещиноватости и микросдвигов по выделенным геоморфоблокам, морфология склонов, антропогенные воздействия. Создание водохранилища и изменение гидрологического режима Волги в целом негативно сказались на инженерно-геологической обстановке прибрежной полосы, так как повышение уровня воды создало благоприятные условия для активного проявления оползневых процессов.

Древние и современные остановившиеся оползни развиты в южной части территории и вдоль уступа Лысогорского массива, где они образуют характерные цирки. Кроме того, небольшие поверхностные оползни-сплывы наблюдаются во многих оврагах и также представляют значительную опасность для объектов города.

Активные оползни располагаются и вдоль берегов Волгоградского водохранилища, в том числе по склонам Соколовогорского и Увекского массивов, где имеют место многочисленные эксплуатационные газонефтяные скважины и подземное газохранилище, что делает эту ситуацию еще более острой.

Наибольший геоэкологический риск в настоящее время представляют оползни в районе Смирновского и Октябрьского ущелий. Площадь первого за три года увеличилась в три раза, что повлекло за собой катастрофические разрушения. Со вторым ущельем также сложилась угрожающая ситуация благодаря неграмотному строительству и подрезке склона. На некоторых участках оползневых склонов проведены укрепительные мероприятия, но в большинстве случаев сохраняется крайне неустойчивое равновесие.

Факторы техногенного риска. К основным его видам относится загрязнение окружающей среды промышленными и бытовыми отходами различного происхождения, образование техногенных физических полей, негативное влияние транспорта на окружающую среду, отработанные карьеры и загрязненные участки нефтепромыслов, а также крупные промышленные зоны и др.

В пределах города загрязнены такие компоненты природной среды, как почвы, грунты, поверхностные и подземные воды. Основным источником загрязнения является транспорт и промышленные предприятия, свалки промышленных и бытовых отходов. Состояние атмосферы, почв и грунтов во многом определяет и качество водных источников, используемых для хозяйственного водоснабжения.
Сброс сточных вод (как очищенных, так и неочищенных) производится в основном в Волгоградское водохранилище, в открытые водоемы (рp. 1-я Гуселка, Назаровка, Черниха и др.), а также в овраги. Загрязнение нефтяными углеводородами происходит в местах переработки и транспортировки нефтепродуктов, часто вместе с промышленными стоками (Соколовогорский массив, Затон, пос. Юбилейный, Увекская нефтебаза и др.).

В Саратове высокая степень загрязнения характерна для всех малых рек. Гидроэкологический риск связан с такими промышленными предприятиями, как ООО «Саратоворгсинтез», OAО «Саратовский НПЗ», а также с проходящими через территорию города газо- и нефтепроводами. Наибольший техногенный геоэкологический риск представляют промышленные отстойники и пруды-накопители нефтепродуктов названных предприятий.

Влияние транспорта. Некоторые виды воздействия транспорта, в первую очередь загрязнение воздуха и повышение уровня шума, выводят его в разряд ведущих факторов геоэкологического риска.

Основное воздействие транспортных средств - привнесение загрязнителей (жидких, твердых, газообразных), обладающих высокой химической активностью и токсичностью, возникновение физических полей техногенного происхождения - таких, как вибрационное, блуждающих потоков и температурное [2]. Наиболее крупными автомагистралями Саратова с высокой плотностью транспортного потока являются ул.Чернышевского, Соколовая, 50 лет Октября, Шехурдина. К ним приурочены крупные сетевые узлы (район ж/д вокзала, Сенного рынка и др.) и участки вложенных сетей (1-я Дачная, 3-я Дачная). Наибольший геоэкологический риск представляет крупный сетевой узел в районе пос. Увек, где железная дорога постоянно испытывает воздействие активного оползня, с одной стороны, и разрушительной деятельности водохранилища - с другой.

Шумовое и вибрационное загрязнение. Распространение этого типа воздействия на окружающую среду совпадает с оживленными автомагистралями, линиями железных дорог, трамвайных и троллейбусных маршрутов, территорией аэропорта, вокзалами, речным портом.

Анализ геоэкологической обстановки Саратова позволил выявить два типа городской территории: благоприятную и неблагоприятную или ограниченно-благоприятную. К благоприятной была отнесена территория, которая в настоящий момент практически не требуют защиты от опасности развития природных и техногенных рисков. Ко второму типу отнесена территория, где уже существует степень опасности природных и техногенных рисков.

Проявления факторов геоэкологического риска определяются вероятностью развития 
нежелательных природных или природно-техногенных явлений в окружающей среде в результате активизации процессов, угрожающих людям или ухудшающих экологическую обстановку. По степени увеличения опасности развития этих процессов выделено три типа геоэкологического риска: вероятный риск (ограниченно-благоприятные территории), потенциальный риск (с опасным проявлением процессов), значительный риск (неблагоприятные территории, в частности с катастрофическим проявлением процессов).

К территориям с вероятной степенью геоэкологического риска отнесены городские территории (центральная часть города от ж/д вокзала до ул. Чернышевской, пос. Юбилейный, Соколовогорский, ул. Азина), где природные и природнотехногенные процессы способны вызвать (но еще не вызвавшие) опасные явления.

На территории потенциального риска развитие одного или одновременно нескольких процессов привело к возникновению опасных явлений в виде подтопления, оползней, провалов, оседания поверхности и др. К таким территориям относятся ул. Чернышевского, 50 лет Октября, пос. Комсомольский, Техстекло, Елшанка и др.

К зонам значительного риска отнесены наиболее опасные территории (склоны Лысогорского и Соколовогорского массивов, вдоль берега Волги, пос. Увек) с активным проявлением экзогенных процессов, на которые накладываются комплексы техногенных факторов, на фоне эндогенно обусловленной геоморфоблоковой структуры или каркаса рельефа, являющихся, по нашему мнению, причиной, нарушающей устойчивость рельефа, и приводящих к формированию антропогенноизмененных территорий.

УДК $911.5(100+470)$

\section{ЛАНДШАФТНЫЕ ОБЛАСТИ И ЗОНЫ В ТРУДАХ А.Н. КРАСНОВА}

\author{
Н. Д. Добрина, Т. Б. Терентьева \\ Саратовский государственный университет, \\ кафедра физической географии и ландшафтной экологии \\ E-mail: geogr@sgu.ru
}

Статья посвящена исследованию трудов одного из выдающихся российских геоботаников А.Н. Краснова. В ней рассматривается одна из его самых интересных идей - идея географических соотношений, которая оказала огромное влияние на дальнейшее развитие учения о географическом ландшафте и природной зоне.

Авторы статьи анализируют основные работы А.Н. Краснова, посвященные описанию и характеристике ландшафтных зон не только России, но и всего мира в целом. В статье также рассматривается идея Краснова о глобальной взаимосвязи всех природных компонентов, которая существенным образом повлияла на изучение проблемы географической зональности.
Для выполнения комплексной оценки степени геоэкологического риска на территории Саратова был использован интегральный показатель факторов риска для определенных территориальных выделов.

В качестве территориальных единиц выбраны ареалы основных морфологических элементов с присущим им геодинамическим режимом, со всеми видами имеющейся техногенной нагрузки на них.

Полученные интегральные показатели факторов риска на различных элементах рельефа позволили выделить территории, отличающиеся степенью проявления геоэкологического риска.

\section{Библиографический список}

1. Осипов В.И. Мегаполисы под угрозой природных катастроф // Вестн. Рос. акад. наук. 1996. Т. 66, №9. C. $773-781$.

2. Рагозин А.Л. Общие положения оценки и управления природным риском // Геоэкология. 1999. №5. C. $417-429$.

3. Ратанова М.П., Битюкова В.Р. Территориальные различия степени экологической напряженности Москвы // Вестн. Моск. ун-та. Сер. геогр. 1999. №1. С.65-71.

4. Худяков Г.И. Геоэкологическая роль геоморфологических структур территории г. Саратова // Рельеф и человек: Материалы Иркут. геоморфологического семинара. Иркутск, 2004. С.146-147.

5. Нестерова О.Е, Худяков Г.И., Штырова В.К. Геоэкологические последствия антропогенных преобразований рельефа г. Саратова // Там же. С. 140-142.

6. Саратов: комплексный геоэкологический анализ / С.А.Артемьев, В.Н.Еремин, А.В.Иванов и др. Саратов, 2003. $248 \mathrm{c}$.

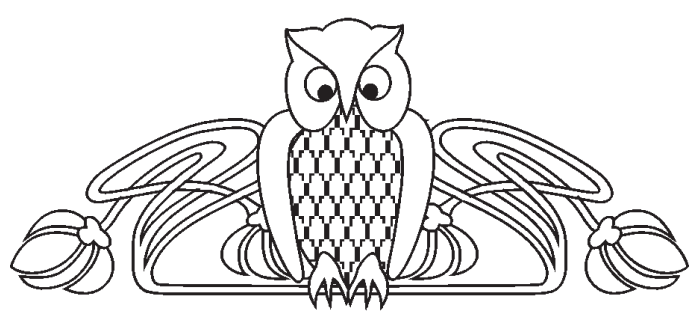

Landscape Areas and Zones in the Works of A.N. Krasnov

\section{N.D. Dobrina, T.B. Terenteva}

The article is focused on the works of one of the most outstanding Russian geobotanics, A.N. Krasnov. A special attention is paid to one of his most interesting ideas concerning the so-called geographical combinations, which influenced dramatically the further development of the studies of geographical landscape and zone.

The authors of the article analyze the main works of A.N. Krasnov devoted to the describing and characterization of landscape areas and zones, not only of Russia, but of the entire world. It is also specially stressed that Krasnov's idea of global interconnection of all the components of nature contributed a great deal to the problem of geographical areas. 